\section{Anatomical and histochemical studies of the somatic embryogenesis of Syagrus oleracea from immature inflorescences}

\author{
Inaê Mariê de Araújo Silva-Cardoso ${ }^{1}$, Filipe Sathler Meira ${ }^{2}$, \\ Ana Cristina Meneses Mendes Gomes ${ }^{3}$ and Jonny Everson \\ Scherwinski-Pereira ${ }^{3 *}$
}

\begin{abstract}
Anatomical and histochemical studies were carried out during the somatic embryogenesis of Syagrus oleracea (Mart.) Becc. from immature inflorescences. Immature rachillas were inoculated on Murashige and Skoog medium with $4.52 \mu \mathrm{M}$ 4-amino-3,5,6-trichloropicolinic acid (Picloram) and 2,4-diclorophenoxyacetic acid. Auxin concentrations were gradually reduced for the formation of somatic embryos, while for plantlet regeneration, embryos were inoculated on a medium without growth regulator. After 270 days, two types of embryogenic calluses were observed in explants under the effect of Picloram: nodular, with a smooth surface and those without definite shape, with an irregular surface, both presenting a meristematic zone with polysaccharide content. Callus progression to the differentiation stage allowed for the conversion of somatic embryos, some with a well-defined protoderm and procambial bundles. The histochemical analysis of the somatic embryos did not identify the presence of polysaccharide and protein reserves, which emphasizes the necessity for optimization of the maturation conditions.
\end{abstract}

Keywords: Arecaceae, palm tree, somatic embryos, morphoanatomy, histochemical characterization.

\section{INTRODUCTION}

Syagrus oleracea (Mart.) Becc., popularly known as gueroba in central Brazil and characterized by its bitter-tasting palm heart, is a palm tree that reproduces via seeds only (Silva-Cardoso et al. 2017). Its germinative process is slow, heterogenous, and marked by low seed viability, owing to the destruction of the embryo by coleopteran Pachymerus nucleorum (Diniz and Sá 1995). Furthermore, its high heterogeneity resulting from cross-pollination is an inconvenience to commercial-scale production.

In order for sustainable exploitation of the species to be undertaken as well as to determine the conditions for the development of future genetic breeding, selection of superior genotypes, development of efficient propagation methods, characterization of the remaining genetic variability, and development of germplasm conservation strategies are required. In this context, somatic embryogenesis is one of the few alternatives for the clonal propagation of the species. Immature inflorescences show promise among the explants that may be used for this technique, due to their low contamination rate (Gadalla et al.
Crop Breeding and Applied Biotechnology 19(4), 444-450, 2019 Brazilian Society of Plant Breeding. Printed in Brazil http://dx.doi.org/10.1590/198470332019v19n4n62

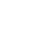


2017), the high embryogenic potential of calluses (Fki et al. 2011), ease of cloning the donor genotype of the material, and other advantages.

One of the remarkable characteristics of somatic embryogenesis is the variety of factors that induce the process, particularly growth regulators at high concentrations, such as the auxins, 4-amino-3,5,6-trichloropicolinic acid (Picloram) and 2,4-diclorophenoxyacetic acid (2,4-D). However, long-term exposure to growth regulators at high concentrations has been associated with the occurrence of abnormalities and, thus, low-quality somatic embryos. Consequently, the development of efficient protocols for somatic embryogenesis that prioritizes low concentrations of growth regulators is necessary to improve the quality of the somatic embryos obtained and to reduce costs. Low concentrations of auxins in the culture media, such as $1.0 \mathrm{mg} \mathrm{L}^{-1}$, have provided good results in inducing somatic embryogenesis in some palm trees (Kriaa et al. 2012, Pádua et al. 2013). In this context, morphoanatomical analysis is essential to demonstrate the correct development of somatic embryos, as well as to identify their origin and to detect possible causes of abnormalities. This study describes the morphoanatomical and histochemical events occurring during the somatic embryogenesis of S. oleracea from immature inflorescences at low auxin concentrations.

\section{MATERIAL AND METHODS}

Experiments were conducted at the Tissue Culture Laboratory II of Embrapa Genetic Resources and Biotechnology in Brasília, DF, Brazil.

\section{Callus induction}

Immature inflorescences of S. oleracea were used as the explant source for this study (Figure 1A). They were harvested from between the internal leaves of the palm heart of an adult plant in the municipality of Itaberaí (lat 16 4' 28.12" S, long 49 43' 18.08" W, alt 705 m asl), GO, Brazil.

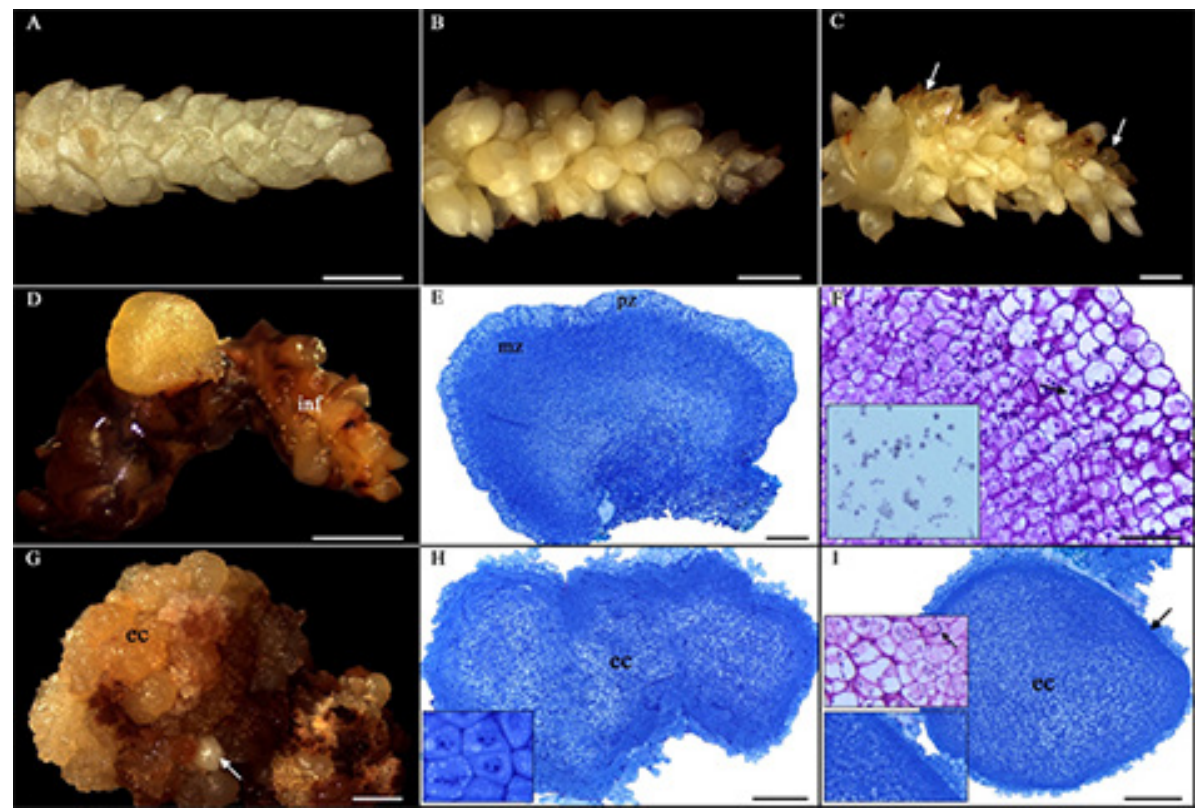

Figure 1. Morphoanatomical analysis of different responses of immature inflorescences of Syagrus oleracea submitted to somatic embryogenesis. A: Explant before inoculation. B: Swollen inflorescence after 30 days of culture. C: Inflorescence with discrete oxidation and callus initiation after 90 days of culture. D: Nodular and yellowish embryogenic callus after 270 days of culture. E: Anatomical segment of the callus mentioned in D; observe meristem and parenchyma zones. F: Starch grains (arrow) in the layer adjacent to the meristem zone evidenced by Periodic Acid Schiff - PAS and Lugol (side inset in detail). G: Embryogenic callus without definite shape and somatic embryos (arrow) after 270 days of culture. H: Anatomical segment of embryogenic callus; note the peripheral cells in intense cell division (lateral square). I: Transition of embryogenic callus into globular-like somatic embryo; observe protoderm in formation (arrow, side inset in detail) and starch grains (arrow, side inset in detail) in the layer adjacent to the meristem zone. Abbreviations: (ec) embryogenic callus; (inf) inflorescence; (mz) meristem zone; (pz) peripheral zone. Bars = A-D: 1mm; G: 2 mm; E, H, I: $200 \mu \mathrm{M}$ and F: $50 \mu \mathrm{M}$. 
Closed and chlorophyll-less spathes of differing lengths $(6.0-41.5 \mathrm{~cm})$, which contained immature inflorescences with different stages of development in their interior, were disinfested in a laminar flow chamber, following the method of Luis and Scherwinski-Pereira (2014). After disinfestation, the spathes were carefully opened, and the rachis containing immature rachillas were exposed. The rachillas were split into segments measuring between 0.5 and $1.0 \mathrm{~cm}$ (Figure $1 \mathrm{~A}$ ) and subjected to one of two treatments characterized by inoculation on Murashige and Skoog basal medium (Murashige and Skoog 1962), supplemented with $30 \mathrm{~g} \mathrm{~L}^{-1}$ sucrose, $0.5 \mathrm{~g} \mathrm{~L}^{-1}$ glutamine, $0.2 \mathrm{~g} \mathrm{~L}^{-1}$ cysteine and either Picloram or 2,4$\mathrm{D}$ at a concentration of $4.52 \mu \mathrm{M}$. The $\mathrm{pH}$ was adjusted to $5.8 \pm 0.1$ prior to the addition of the gelling agent $\left(2.5 \mathrm{~g} \mathrm{~L}^{-1}\right.$ Phytagel). The medium was sterilized by autoclaving at 121 으, for 20 minutes, at a pressure of 1.5 atm. The rachillas were inoculated in 14 Petri dishes $(15 \times 90 \mathrm{~mm})$ containing approximately $25 \mathrm{~mL}$ of culture medium, with five explants in each one. Once inoculated, the materials were kept in the dark, in a growth room at $25 \pm 2$ oC, for 270 days, without subculturing.

\section{Differentiation of somatic embryos}

In order for the somatic embryos to be differentiated, explants containing embryogenic calluses were transferred to the same formulation of the culture medium of the induction stage, supplemented with $30 \mathrm{~g} \mathrm{~L}^{-1}$ sucrose, $0.5 \mathrm{~g} \mathrm{~L}^{-1}$ glutamine, $0.5 \mathrm{~g} \mathrm{~L}^{-1}$ cysteine, $0.5 \mathrm{~g} \mathrm{~L}^{-1}$ hydrolyzed casein, and either Picloram or 2,4-D, at concentrations that were reduced monthly to $2.26 \mu \mathrm{M}, 0.45 \mu \mathrm{M}$, and $0.045 \mu \mathrm{M}$. At this stage, the embryogenic aggregates were kept in a dark growth room at $25 \pm 2{ }^{\circ} \mathrm{C}$ for 90 days (totaling 360 days of culturing).

\section{Regeneration of plantlets}

For conversion into plants, somatic embryos similar to the torpedo stage were inoculated on the regeneration medium, which was the same as the original basic medium with the addition of $30 \mathrm{~g} \mathrm{~L}^{-1}$ sucrose, $0.5 \mathrm{~g} \mathrm{~L}^{-1} \mathrm{glutamine} 0.5 \mathrm{~g} \mathrm{~L}^{-1}$ cysteine, $0.5 \mathrm{~g} \mathrm{~L}^{-1}$ hydrolyzed casein, and $2.5 \mathrm{~g} \mathrm{~L}^{-1}$ activated charcoal, for 150 days (totaling 510 days of culturing), until the development of root and shoot. Explants were cultured in $250 \mathrm{~mL}$ glass flasks in a growth room at $25 \pm 2{ }^{\circ} \mathrm{C}$, luminosity at $100 \mu \mathrm{m} \cdot \mathrm{m}^{-2} \mathrm{~s}^{-1}$, for a $16 \mathrm{~h}$ photoperiod.

\section{Anatomical and histochemical analysis}

Samples of uncultured materials from different callogenic formations (after 270 days of culturing) and somatic embryos at different stages of development (after 360 days of culturing) were harvested for anatomical analyses. Fixation, dehydration, and embedding of the collected plant materials were carried out according to the following protocol: fixation in a modified Karnovsky solution (Karnovsky 1965), with 4\% paraformaldehyde, $2.5 \%$ glutaraldehyde, and $0.05 \mathrm{M}(\mathrm{pH}$ 7.2) sodium cacodylate buffer, for $24 \mathrm{~h}$, followed by three washes in a sodium cacodylate solution $(0.05 \mathrm{M}, \mathrm{pH} 7.2)$, for $1 \mathrm{~h}$ each. Dehydration in an ascending alcohol series (30 - 100\%), for $1 \mathrm{~h}$ was then carried out, followed by histological infiltration (Leica, Germany), according to the manufacturer's specifications.

Segments $(3-7 \mu \mathrm{m})$ obtained from a manual rotatory microtome, were stretched and adhered to microscopic slides on a plate heated to $40^{\circ} \mathrm{C}$. They were then stained with toluidine blue $(0.5 \%)$ for structural characterization $\left(\mathrm{O}^{\prime}\right.$ Brien et al. 1964). The segments obtained from the embedded material were subjected to the following histochemical tests: periodic acid-Schiff (PAS) (O'Brien and McCully 1981), used to identify neutral polysaccharides; Lugol's solution (Johansen 1940), to detect starch grains; and xylidine ponceau (XP), used for the visualization of proteins (Vidal 1970). Images were obtained and analyzed with a Leica DM 750 microscope and the Leica Application Suite EZ program.

Scanning Electron Microscopy (SEM) of somatic embryos and Transmission Electron Microscopy (TEM) of zygotic embryos of the species followed the protocol by Luis and Scherwinski-Pereira (2014) and Borji et al. (2017), respectively, with modifications.

\section{RESULTS AND DISCUSSION}

At 30 days of culture, swelling of most explants was observed (Figure 1B). At 90 days, mild oxidation and incipient callogenic formations (Figure 1C) were observed. A watery primary callus with a slimy consistency, a compact and nodular embryogenic callus with yellowish coloration, most of which had a smooth surface (Figure 1D), and an embryogenic 
callus without definite shape and with an irregular surface (Figure 1G) were observed after 270 days of culture on a basal medium. It is worth noting that embryogenic formations were only reported in explants under the effect of Picloram. In addition to calluses, the formation of somatic embryos in the globular-like stage (Figure 1G), some of them fused (Figure 2 ), were verified. The time required for the formation of embryogenic structures from immature inflorescences of $S$. oleracea was relatively short compared to that reported for Elaeis guineensis by Teixeira et al. (1994), which required 81 weeks (567 days).

Analysis of embryogenic calluses obtained from immature inflorescences revealed different anatomical characteristics. The compact, nodular, yellowish embryogenic callus with a smooth surface (Figure 1D) displayed a large internal zone composed of cells with meristem characteristics (small cells with a dense cytoplasm, voluminous nuclei, evident nucleoli, fragmented vacuoles, and intense cell division) and a narrower peripheral zone formed by cells with parenchyma characteristics, which were highly vacuolated (Figure 1E). The bordering region between the two zones was similar to that described as cambium-like by Verdeil et al. (1994), in calluses from immature inflorescences of Cocus nucifera.

Embryogenic calluses without definite shape and with irregular surfaces (Figure 1G) showed an opposite pattern to the compact, nodular ones previously discussed. They were characterized by parenchyma cells with variable vacuolation, placed more internally, and by cells with meristem characteristics (at different phases of mitosis), placed within the peripheral region of the callus (Figure $1 \mathrm{H}$ ). The histological analysis of this last callus suggests a multicellular origin of the somatic embryos obtained. Note the acquisition of the protoderm by the multicellular complex (Figure 1I). In
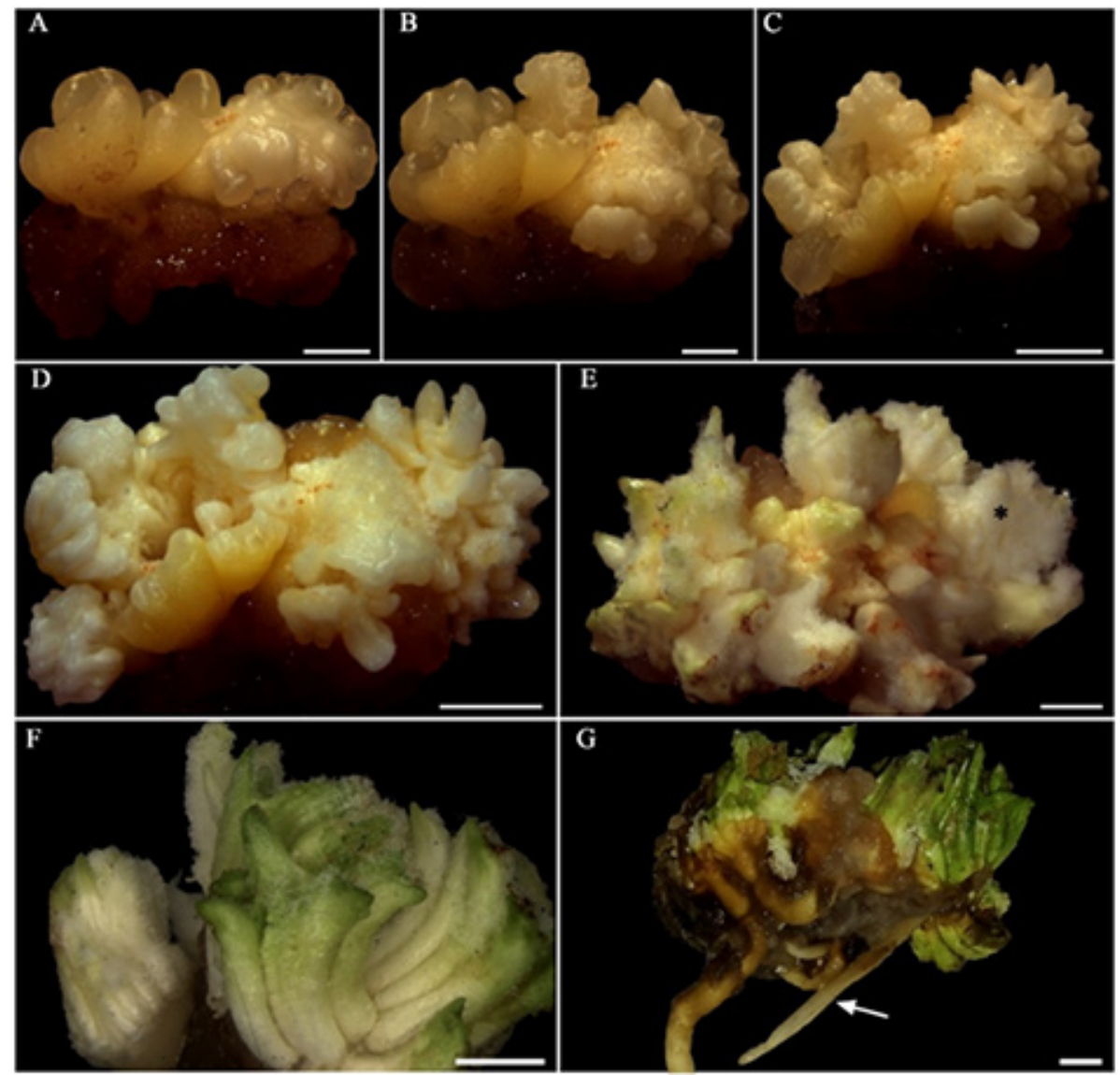

Figure 2. Morphological evolution of primary callus into plantlets of Syagrus oleracea from immature inflorescence in a medium with Picloram. A-D: Development of somatic embryos at 30,60, 120 and 150 days, respectively, in induction medium. E, F: Somatic embryos in regeneration medium; note the presence of trichomes $\left({ }^{*}\right)$, green appearance and fusion. G: Fused plantlets. Bars = A: 1 $\mathrm{mm}$ and B-G: $2 \mathrm{~mm}$. 
histochemical terms, PAS and Lugol reagents revealed significant polysaccharide content (starch grains), mainly in the peripheral zone adjacent to the meristemic one, in the two embryogenic calluses analyzed (Figures $1 \mathrm{~F}, \mathrm{I}$ ), which may potentially subsidize them energetically.

During the differentiation of somatic embryos, the gradual conversion of embryogenic calluses into somatic embryos was also observed. This was coupled to the evolution of somatic embryos formed in the induction phase towards more advanced stages. They are characterized by an opaque whitish coloration, some of which have an elongated shape similar

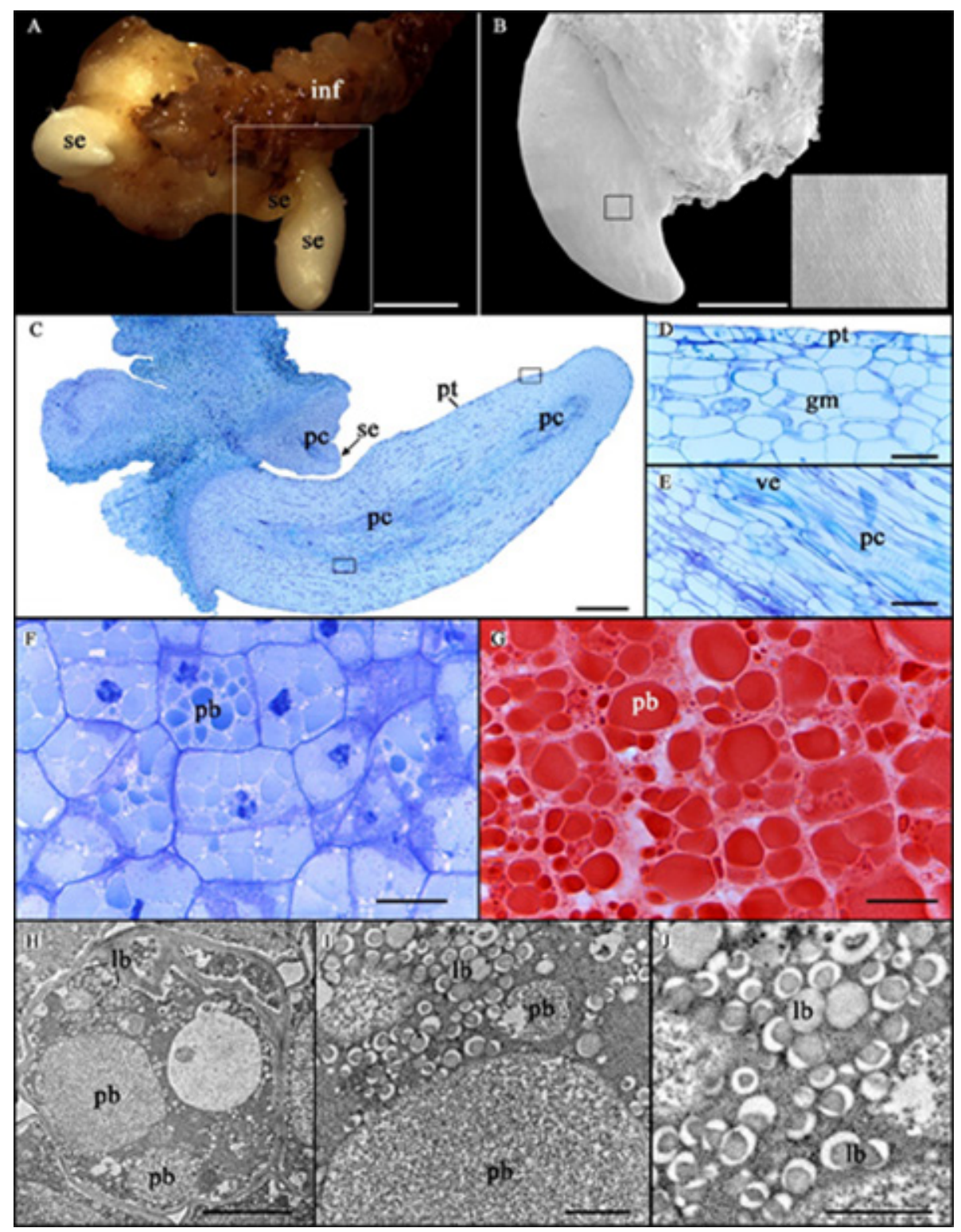

Figure 3. Morphoanatomical analysis of somatic embryos developed from embryogenic calluses of immature inflorescence, and anatomical and ultrastructural analysis of zygotic embryos of Syagrus oleracea. A: Somatic embryos. B: Surface of somatic embryo by Scanning Electron Microscopy. C: Somatic embryos with protoderm and procambium. D: Detail of the protoderm and ground meristem. E: Detail of the procambium. F: Ground meristem of zygotic embryo. G: Protein bodies stained with Xylidine Ponceau in cells of the ground meristem of zygotic embryo. $\mathrm{H}$ : Cell ultrastructure of the ground meristem of zygotic embryo; note conspicuous protein bodies and abundant lipid bodies. I, J: $\mathrm{H}$ in higher magnification. Abbreviation: (pb) protein body; (lb) lipid body; (se) somatic embryo; (ve) vessel element; (inf) inflorescence; (gm) ground meristem; (pc) procambium; (pt) protoderm. Bars = A: 2 mm; B, C: 500 $\mu \mathrm{M} ; \mathrm{D}, \mathrm{E}: 50 \mu \mathrm{M} ; \mathrm{F}, \mathrm{G}: 20 \mu \mathrm{M} ; \mathrm{H}: 2 \mu \mathrm{M}$ and I, J: $0.5 \mu \mathrm{M}$. 
to the torpedo stage (Figure 3A). It should be emphasized that the process was sharply asynchronous and presented a relatively high rate of fused somatic embryos (Figure 2), which may be related to the disruption during the polarization of embryogenic units of multicellular origin (Michaux-Ferrière et al. 1992), as proposed in this study. The observed asynchrony has also been recurrent in other embryogenic systems (Scherwinski-Pereira et al. 2010, Pádua et al. 2017).

After the first 120 days in the regeneration medium, two different responses were observed in the medium totally devoid of growth regulators and under light conditions: germination (the emergence of the aerial part and root system) of a few somatic embryos (Figure 2G) and the sole emergence of the aerial part of a significant portion of somatic embryos which gradually acquired a green pigmentation. Although some clusters of somatic embryos emitted both meristems, they displayed a limited number of roots for multiple shoots, which hampered the isolation of each shoot and subsequent acclimatization, as reported by Jayaraj et al. (2015). Since the somatic embryos in which only the aerial part emerged did not survive, the adoption of an additional rooting treatment was not possible.

With regards to the anatomy of somatic embryos, the presence of the protoderm (Jalil et al. 2008) and evident procambial bundles (regardless of the callus - without connection to maternal tissue) confirms them as true somatic embryos (Raju et al. 2014) (Figure 3). The histochemical analysis did not identify the presence of polysaccharide and protein reserves in the somatic embryos obtained. It is worth mentioning that the principal reserves of zygotic embryos of the species are protein and lipids (Figure 3F-J), with starch limited to the remnants in the haustorial region and near the plumule (data not shown).

The total absence of protein in somatic embryos at a more advanced stage of development agrees with past research on palms (Goh et al. 2001, Sané et al. 2006) and emphasizes the necessity for optimization of the maturation conditions, for example, by manipulation of the components of the medium culture. The latter enables the accumulation of sufficient reserves for satisfactory germination of somatic embryos obtained. According to Joy IV et al. (1991), several factors may influence the pattern of reserve deposition during somatic embryogenesis, such as the absence of maternal influence, water content, growth regulators, the concentration of salts, carbon source, and stability of the osmotic environment.

\section{CONCLUSION}

Picloram at low concentration $(4.52 \mu \mathrm{M})$ enables the formation of embryogenic calluses from immature inflorescences in S. oleracea. The process is asynchronous with a probable multicellular origin. Under the conditions used in this study, somatic embryos formed were deficient in polysaccharide and protein reserves, which indicates the need for further optimization of the final stages of the process.

\section{ACKNOWLEDGEMENTS}

This work was supported by the Coordenação de Aperfeiçoamento de Pessoal de Nível Superior (Capes/Embrapa 001-2011/Grant 39) and Conselho Nacional de Desenvolvimento Científico e Tecnológico (CNPq Grant 426637/2016-0) through financial aid and fellowships.

\section{REFERENCES}

Borji M, Bouamama-Gzara B, Chibani F, Teyssier C, Ammar AB, Mliki A, Zekri S and Ghorbel A (2017) Micromorphology, structural and ultrastructural changes during somatic embryogenesis of a Tunisian oat variety (Avena sativa L. var 'Meliane'). Plant Cell, Tissue and Organ Culture 132: 329-342.

Diniz JA and Sá LF (1995) A cultura da guariroba. EMATER-GO, Goiânia, $16 p$.

Fki L, Masmoudi R, Kriaâ W, Mahjoub A, Sghaier B, Mzid R, Mliki A, Rival A and Drira N (2011) Date Palm Micropropagation via Somatic Embryogenesis. In Jain SM, Al-Khayri JM and Johnson DV (eds) Date palm biotechnology. Springer, Dordrecht, p. 47-68.
Gadalla EE-DG (2017) Direct organogenesis from immature female inflorescence of date palm by gradual reduction of 2,4-D concentration. In Al-Khayri JM, Jain SM and Johnson DV (eds) Date palm biotechnology protocols. Tissue Culture Applications, Humana Press, New York, p. 26-35.

Goh DKS, Bon M-C, Aliotti F, Escoute J, Ferrière N and Monteuuis O (2001) In vitro somatic embryogenesis in two major rattan species: Calamus merrillii and Calamus subinermis. In Vitro Cellular \& Developmental Biology - Plant 37: 375-381.

Jalil M, Chee WW, Othman RY and Khalid N (2008) Morphohistological examination on somatic embryogenesis of Musa acuminata cv. Mas (AA). Scientia Horticulturae 117: 335-340.

Jayaraj KL, Bhavyashree U, Fayas TP, Sajini KK, Rajesh MK and Karun 
A (2015) Histological studies of cellular differentiation during somatic embryogenesis of coconut plumule-derived calli. Journal of Plantation Crops 43: 196-203.

Johansen D (1940) Plant microtechnique. Mc Graw Hill, New York, 523p.

Joy IV RW, Yeung EC, Kong L and Thorpe TA (1991) Development of white spruce somatic embryos: I. Storage product deposition. In Vitro Cellular \& Developmental Biology 27: 32-41.

Karnovsky MJ (1965) A formaldehyde-glutaraldeyde fixative of high osmolality for use in electron microscopy. The Journal of Cell Biology 27: $137-138$.

Kriaa W, Sghaier B, Masmoudi F, Benjemaa R and Drira N (2012) The date palm (Phoenix dactylifera L.) micropropagation using completely mature female flowers. Comptes Rendus Biologies 335: 194-204.

Luis ZG and Scherwinski-Pereira JE (2014) An improved protocol for somatic embryogenesis and plant regeneration in macaw palm (Acrocomia aculeata) from mature zygotic embryos. Plant Cell Tissue and Organ Culture 1180: 485-496.

Michaux-Ferrière N, Grout H and Carron MP (1992) Origin and ontogenesis of somatic embryos in Hevea brasiliensis (Euphorbiaceae). American Journal of Botany 79: 174-180.

Murashige T and Skoog F (1962) A revised medium for rapid growth and bioassays with tobacco tissue cultures. Physiologia Plantarum 15: 473-497.

O'Brien TP and McCully ME (1981) The study of plant structure: principles and selected methods. Termarcarphi PTY, Melbourne, 357p.

O'Brien TP, Feder N and McCully ME (1964) Polychromatic staining of plant cell walls by toluidine blue O. Protoplasma 59: 368-373.
Pádua MS, Paiva LV, Labory CRG, Alves E and Stein VC (2013) Induction and characterization of oil palm (Elaeis guineensis Jacq.) pro-embryogenic masses. Anais da Academia Brasileira de Ciências 85: 1545-1556.

Pádua MS, Santos RS, Labory CRG, Stein VC, Mendonça EG, Alves E and Paiva LV (2017) Histodifferentiation of oil palm somatic embryo development at low auxin concentration. Protoplasma 255: 285-295.

Raju CS, Aslam A, Kathiravan K, Palani P and Shajahan A (2014) Direct somatic embryogenesis and plant regeneration from leaf sheath explants of mango ginger (Curcum amada Roxb.). In Vitro Cellular \& Developmental Biology - Plant 50: 752-759.

Sané D, Aberlenc-Bertossi F, Gassama-Dia YK, Sagna M, Trouslot MF, Duval $Y$ and Borgel A (2006) Histocytological analysis of callogenesis and somatic embryogenesis from cell suspensions of date palm (Phoenix dactylifera). Annals of Botany 98: 301-308.

Scherwinski-Pereira JE, Da Guedes RS, Fermino Jr PCP, Silva TL and Costa FHS (2010) Somatic embryogenesis and plant regeneration in oil palm using the thin cell layer technique. In Vitro Cellular \& Developmental Biology - Plant 46: 378-385.

Silva-Cardoso IMA, Souza AM and Scherwinski-Pereira JE (2017) The palm tree Syagrus oleracea Mart. (Becc.): A review. Scientia Horticulturae 225: 65-73.

Teixeira JB, Söndahl MR and Kirby EG (1994) Somatic embryogenesis from immature inflorescences of oil palm. Plant Cell Reports 13: 247-250.

Verdeil JL, Huet C, Grosdemange F and Buffard-Morel J (1994) Plant regeneration from cultured immature inflorescences of coconut (Cocos nucifera L.): evidence for somatic embryogenesis. Plant Cell Reports 13: 218-221.

Vidal BC (1970) Dichroism in collagen bundles stained with xylidinePonceau 2R. Ann Histochim 15: 289-296.

(cc) EY This is an Open Access article distributed under the terms of the Creative Commons Attribution License, which permits unrestricted use, distribution, and reproduction in any medium, provided the original work is properly cited. 